\title{
Osmanlı Modernleşmesinde Anglosakson Etkisi (1839-1852)
}

Anglo-Saxon Impact on the Ottoman Modernisation (1839-1852)

\section{Çağrı ERHAN}

Prof. Dr., Uluslararası İlişkiler Bölümü, Altınbaş Üniversitesi

\section{İşat SARIALIOĞLU}

Dr., Uluslararası İlişkiler Bölümü, Ankara Hacı Bayram Veli Üniversitesi

\section{Bu makaleye atıf için}

Erhan, Çağrı ve Sarıalioğlu, İrşat, "Osmanlı Modernleşmesinde Anglosakson Etkisi (18391852)”, Uluslararası İiş̧kiler, Cilt 16, Sayı 63, 2019, s. 87-104, DOI: 10.33458/uidergisi.621318

Makaleye Erişim İçin: https://dx.doi.org/10.33458/uidergisi.621318

Makale Gönderim: 26 Eylül 2018

Son Düzeltme: 11 Nisan 2019

İnternet Yayım: 01 Eylü1 2019

Basım Tarihi: 01 Eylül 2019

\section{Uluslararası İlişkiler Konseyi Derneği | Uluslararası İlişkiler \\ E-Posta: bilgi@uidergisi.com.tr}

Bu makalenin tüm hakları Uluslararası İişkiler Konseyi Derneği’ne aittir. Önceden yazılı izin almadan hiçbir iletişim, kopyalama ya da yayın sistemi kullanılarak yeniden yayımlanamaz, çoğaltılamaz, dağıtılamaz, satılamaz veya herhangi bir şekilde kamunun ücretli/ücretsiz kullanımına sunulamaz. Akademik amaçlı alıntılar bu kuralın dışındadır. Yazıda belirtilen fikirler yalnızca yazarına/yazarlarına aittir. UİK Derneğini, editörleri ve diğer yazarları bağlamaz. 


\title{
Osmanlı Modernleşmesinde Anglosakson Etkisi (1839-1852)
}

\author{
Çağn ERHAN \\ Prof. Dr., Altınbaş Üniversitesi, Uluslararası İlişkiler Bölümü, İstanbul. \\ E-posta:cagri.erhan@altinbas.edu.tr \\ İrşat SARIALİOĞLU \\ Dr., Ankara Hacı Bayram Veli Üniversitesi, Uluslararası İlişkiler Bölümü, Ankara. \\ E-posta: irsatsarialioglu@gmail.com
}

\section{ÖZET}

Tanzimat Fermanının ilanını (1839) takip eden dönemde Osmanlı İmparatorluğu, idare mekanizması ve felsefesiyle ilgili birçok alanda önemli dönüşüm süreçlerinden geçmiştir. Bu çalışma, söz konusu süreçlerdeki Britanya ve ABD etkisini açığa çıkarmayı ve anlamlandırmayı amaçlamaktadır. Bu bağlamda hukuk, ekonomi, vatandaşlık, askeriye, eğitim gibi alanlara dair Britanya ve ABD'nin "tavsiyeleri” araştırılmış ve ardından bu alanlarda meydana gelen dönüşüm süreçlerinde söz konusu tavsiyelerin ne kadar etkili olduğuna bakılmıştır. Böylelikle Anglosakson etkisi, bugüne kadar anlatılagelmiş olan Fransız etkisiyle karşılaştırılarak konuya dair daha geniş perspektifli bir analiz sunmak hedeflenmiştir.

Anahtar Kelimeler: Osmanlı Modernleşmesi, Tanzimat, Osmanlı İmparatorluğu, Britanya, ABD

\section{Anglo-Saxon Impact on the Ottoman Modernisation (1839-1852)}

\begin{abstract}
The Ottoman Empire went through a highly significant change and transformation process at the period following the declaration of Tanzimat Edict (1839) regarding the mechanism and philosophy of administration. This article aims to reveal and explain the influence of Britain and the USA on the above mentioned processes within the Ottoman Empire. In this context, the "recommendations" from Britain and the USA were researched regarding the areas such as law, economy, citizenship, military and education; and then the question to what extent these recommendations were influential on the transformation process that occurred within these areas were handled. The Anglo-Saxon influence was compared to that of French which has already been covered in the literature.
\end{abstract}

Keywords: Ottoman Modernization, Tanzimat, Ottoman Empire, Britain, USA 


\section{Giriş}

Osmanlı İmparatorluğu'nun gerek bekasına yönelik kaygıları gerek uluslararası sistemde yer edinme hedefi sebebiyle Lale Devri’nden itibaren giriştiği modernleşme hamleleri, III. Selim ve II. Mahmud dönemlerindeki birçok reform ve projenin ardından Tanzimat Fermanı, Islahat Fermanı ve Kanun-i Esâsi gibi hukuksal metinler üreterek devam etmiştir. Bu süreçlerde devlet erkini elinde tutanların bilinçli yönelişlerinin yanı sıra, İmparatorluğun kurduğu dış münasebetler de önemli bir yer işgal etmiştir.

Modernleşmenin ilk hamlelerinin gerçekleştirildiği 18. yüzyılda başat güç mertebesinde olan ve Osmanlı İmparatorluğu ile çok yönlü ve katmanlı ilişkileri bulunan Fransa’nın, İmparatorluktaki süreçlere etkisi derin olmuştur. Fakat Fransız Devrimi'yle başlayan ve kesintisiz savaşlarla 1815'e kadar devam eden çalkantılı iç siyasal dinamikleri, Fransa'ya, askerî işbirliklerinin ve mevcut iktisadi ayrıcalıklarının ötesinde bir dönüştürücü misyon üstlenme imkanı vermemiştir. Takip eden yıllar ise Fransa'nın başat güç olma vasfını giderek yitirmesine ve Britanya’nın küresel liderliğe hızlı adımlarla ilerlemesine sahne olmuştur. Hal böyle olunca, Dersaadet'in birçok farklı faktörden beslenen bir iştiyakla Fransa'ya olan ilgisi devam etmekle beraber Britanya da Osmanlı devlet ricalinin ilgi odağı haline gelmiştir.

$\mathrm{Bu}$ duruma rağmen mevcut literatürümüzün Fransız etkisi üzerine olan vurgusu, konuya Anglosakson etkisi bağlamında bakan çalışmaların ortaya çıkmasını bir anlamda zorunlu kılmaktadır. $\mathrm{Bu}$ makale de Osmanlı modernleşmesi ile dış münasebetler arasında bağ kurulduğunda ilk akla gelen Fransa örneğinin yanı sıra, bu hususlardaki Anglosakson etkisinin bugüne değin hak ettiği ilgiyi görmediği fikrinden doğmuştur. Bu bağlamda çalışma dâhilinde, Osmanlı İmparatorluğu’nun geçirdiği modernleşme sürecinin kökenine, Britanya ve ABD’yle kurduğu münasebetler bağlamında bakılmış ve bu süreçteki Anglosakson etkisi üzerinden yeni ve alternatif bir bakış açısı geliştirmek hedeflenmiştir. Tanzimat Fermanı́nın ilanını takip eden dönemde devlet eliyle gerçekleştirilen modernleşme hamleleri ise çalışmanın tematik ve kronolojik sınırlarını ihtiva etmektedir. Bu bağlamda çalışmaya 1839 yılından itibaren gerçekleşen yenileşme hamleleriyle başlanmış ve Kırım Savaşı’nın başlangıcına kadar olan erken Tanzimat dönemine odaklanılmıştır. Zira, tıpkı Islahat Fermanı ve devamında gerçekleşen yenileşme hamleleri gibi Kırım Savaşı dönemine ait modernleşme hamleleri de ayrı ve müstakil çalışmaların konusunu oluşturacak muhteviyattadır.

1833 Hünkâr İskelesi Antlaşması'nın ardından yeniden şekillenen Britanya’nın Yakındoğu politikasında Osmanlı İmparatorluğu’nun ayakta kalması ve Rusya karşısında güçlenmesi hayati bir önem arz etmekteydi. Bu amacın gerçekleşmesi için Osmanlı İmparatorluğu’nun modernleş(tiril) mesi/yenileş(tiril)mesi ve idari sisteminde reforma gidilmesi elzem görülmekteydi. ${ }^{1} \mathrm{Bu}$ açıdan ordudan donanmaya, idari yapıdan finansa ve hatta sağlık sistemine, İmparatorluğun tüm kurumları mercek altındaydı. ${ }^{2}$ Osmanlı İmparatorluğu da uluslararası alanda aleyhine gelişen olaylarda desteğine ihtiyaç duyduğu Britanya'yla kurulacak işbirliği vasıtasıla bahsi geçen eksikliklerin giderilmesini

1 Harold Temperley, "British Policy towards Parliamentary Rule and Constitutionalism in Turkey (1830-1914)", Cambridge Historical Journal, Cilt 4, No 2, 1933, s. 156; Frank Edgar Bailey, British Policy and the Turkish Reform Movement: A Study in Anglo-Turkish Relations 1826-1853, New York, Howard Fertig, 1970, ss. 61-62; Frederick Stanley Rodkey, "Lord Palmerston and the Rejuvenation of Turkey 1830-1841 Part I", The Journal of Modern History, Cilt. 1, No. 4, 1929, ss. 572-573.

2 Frederick Stanley Rodkey, "Lord Palmerston and the Rejuvenation of Turkey, 1830-1841, Part II, 1839-1841: Alexander Prize Essay”, Transactions of the Royal Historical Society, Fourth Series, Cilt 12, 1929, s. 165, 190. 
arzulamaktaydı. Dönemin padişahı II. Mahmud'un söz konusu reform çabaları Britanya’nın, Osmanlı politikası ve İmparatorluğun kurtarılabilir olduğu fikriyle de uyum arz etmekteydi. ${ }^{3}$

Britanya'nın Osmanlı İmparatorluğu'nun modernleştirilmesi politikasıyla uyumlu olan bir diğer gelişme de 1839 tarihli Tanzimat Fermanı'dır. 1839 yılında II. Mahmud'un ani ölümü sonucu tahta çıkan genç Sultan Abdülmecid'in önünde acilen çözmesi gereken Mısır krizi vardı ve bu krizde Britanya'nın desteğini sağlamanın en önemli yollarından birinin de İmparatorluğun modernleştirilmesine dair garantinin verilmesi olduğu bilinmekteydi. ${ }^{4} \mathrm{Bu}$ durum, diğer taraftan dönemin Dışişleri Bakanı Mustafa Reşid Paşa’nın uzun zamandır aklında olan reform planlarını daha kolay uygulayabileceği bir konjonktürün ortaya çıkışına da zemin hazırlamıştı. Tanzimat'ın mimarı olarak anılan Reşid Paşa, Osmanlı İmparatorluğu'nun ayakta kalmasının ancak İmparatorluğun reformlar vasıtasıyla yeniden yapılandırılmasıyla mümkün olacağına inanmaktaydı. 1838 yılında Reşid Paşa'nın yeniden nükseden Mısır krizine karşı bir ittifak gerçekleştirebilmek amacıyla Londra'ya gitmesi de söz konusu planlarını hızlandırmasını beraberinde getirmişti. Bu çerçevede Reşid Paşa Londra'da bulunduğu sırada Dışişleri Bakanı Lord Palmerston’la görüşmüş ve Palmerston'a Osmanlı İmparatorluğu'nda yapılması gereken reformlara dair hazırladığı taslağı iletmişti. Söz konusu taslağın içeriği aslında birkaç ay sonra ilan edilecek Tanzimat'ın habercisi niteliğindeydi. Mustafa Reşid Paşa, bu memorandumla Tanzimat'ı açlklamakta ve Britanya'dan bu hususta yardım talep etmekteydi. Reşid Paşa tarafından kaleme alınan memorandum Palmerston tarafından memnuniyetle karşılandı. ${ }^{5}$ Bu gelişmenin ardından Palmerston, İstanbul Büyükelçisi Ponsonby'nin görevlerinin arasına Reşid Paşa'nın desteklenmesini de ekledi ${ }^{6}$

Tanzimat Fermanı'nın ilanıyla, Osmanlı ile Britanya arasında İmparatorluğun modernleşmesi hususunda kurulan fikir ve hedef ortaklığı çok daha ileri bir boyuta taşınmıştır. Fermanın ilanının ardından 1841 yılında İstanbul'a (bir kez daha) büyükelçi olarak atanan Stratford Canning'in ${ }^{7}$ Abdülmecid ile gerçekleştirdiği ilk görüşmede, Hükümetinin Sultan’dan "mahir, akla yatkın, mutedil ve ölçülü tedbirleri hayata geçirerek İmparatorluğun yaşamasını sağlamasını arzuladığını” açıkça belirtmesi de bu durumu kantlar niteliktedir. İmparatorluğun modernleşmesine ve Tanzimat

3 Sir Charles Webster, The Foreign Policy of Palmerston 1830-1841, Cilt 2, Londra, G. Bell \& Sons, 1951, s. 657.

4 Bailey, British Policy, s. 180.

5 Ahmet Dönmez, Osmanlı Modernleşmesinde İngiliz Etkisi: Diplomasi ve Reform (1833-1841), İstanbul, Kitap Yayınevi, 2014, ss. 248-261; Reşat Kaynar, Mustafa Reşit Paşa ve Tanzimat, Ankara, TTK, 2010, ss.153-156; Şerif Mardin, Yeni Osmanl Düşüncesinin Doğuşu, çev. Mümtaz’er Türköne et al., İstanbul, İletişim, 2009, ss.197-198. Bahsi geçen memorandum için bkz. Frederick Stanley Rodkey, "Reshid Pasha's Memorandum of August 12, 1839”, Journal of Modern History, Cilt 2, No 2, 1930, ss. 251-257; Ahmet Dönmez, “Mustafa Reşid Paşa’nın İkinci Londra Elçiliği ve Tanzimat Reformlarına Dair Memorandumu”, Tarihin Peşinde, No 6, 2011, ss. 1-20; Turgut Subaşı, "Anglo-Ottoman Relations In The Nineteenth Century: Mustafa Reşid Paşa’s Memorandum to Palmerston, 11 August 1839”, International Journal of Human Sciences, Cilt 8, No 1, 2011, ss. 1731-1746.

6 Rodkey, Lord Palmerston, Part I, ss. 575-577, Rodkey, Lord Palmerston, Part II, s. 176.

7 Startford Canning 19. yüzyılda birçok defa Osmanlı İmparatorluğunda görev yapmış meşhur bir Britanyalı diplomattır. Yunan İhtilalinden, Kırım Savaşı'na, Tanzimat sürecinden Islahat Fermanı'na 19. yüzyılın birçok önemli hadisesinde karşımıza çıkan bu meşhur diplomatın Osmanlı İmparatorluğu'nun dış politikası ve modernleşme siyasetindeki rolü oldukça önemlidir. Stratford Canning ile ilgili ayrıntılı bilgi için bkz. Stanley Lane Poole, The Life of the Right Honourable Stratford Canning: Viscount Stratford De Redcliffe, Cilt I-II, Londra, Longmans, Green and Co, 1888; Stanley Lane Poole, Lord Stratford Canning'in Türkiye Hatıraları, çev. Can Yücel, Ankara, Yurt Yayınları, 1988; Turgut Subaşı, "Britanya Büyükelçisi Stradford Canning'in Bab-1 Ali ile İlişkileri”, VIII. Milletlerarası Türkoloji Kongresi, 30 Eylül- 4 Ekim 2013, İstanbul, İstanbul Üniversitesi Yayınları, 2014, ss. 805-815; İrşat Sarıalioğlu, Stratford Canning'in İstanbul Büyükelçiliği (1841-1847), Yayınlanmamış Doktora Tezi, Hacettepe Üniversitesi, 2017. 
Fermanı'nın işaret ettiği reformların hayata geçirilmesine 'nezaret etmek' artık Britanya büyükelçisinin talimatnamesinin esasını oluşturmaktaydı. ${ }^{9}$

Britanya örneğinin ve Britanya'yla kurulan ilişkinin gerisinde kalsa da dönemin Osmanlı$\mathrm{ABD}$ ilişkileri de diplomasi ve modernleşme bağlamında önemli ve yeni gelişmelere işaret etmekteydi. $\mathrm{Bu}$ dönemde $\mathrm{ABD}$, yükselen yeni bir güç olmasının yanı sıra alternatif bir müttefik ve rol model olarak da Osmanlı devlet ricalinin ilgisini çekmeye başlamıştı. Zira, Osmanlı modernleşmesi İmparatorluğun yıkılmasına karşı zaruri bir önlem olarak ortaya çıkmış ve ideolojik olmaktan ziyade pragmatik bir tutumla süreç içerisinde ortaya çıkan ihtiyaçlara pratik cevaplar üreterek ilerleyen bir üsluba sahip olmuştu. Bu noktada, kendi beka meselesi olarak değerlendirdiği Doğu Sorununun dünya gündeminin baş sıralarını işgal ettiği bir dönemde, Osmanlı İmparatorluğu'nun modernleşme konusunda birçok farklı kaynaktan beslenmesi, bir diğer ifadeyle alternatifleri çeşitlendirmesi doğal ve anlaşılır bir durumdu. Bu noktadaki en önemli kıstas ise dış politikada uyum prensibiydi. Aslında, 19. yüzyılda özellikle de Tanzimat dönemi modernleşme hamlelerinde Britanya'yı Fransa'nın önüne geçiren de büyük ölçüde bu prensipti. ${ }^{10}$ Zira Britanya, yukarıda bahsedildiği üzere, Hünkâr İskelesi’nin ardından İmparatorluğun stratejik ortağına dönüşmüştü. Diğer taraftan, Mısır Meselesinin ardından Doğu Sorununun kalbi Cebel-i Lübnan'da atıyordu. Dürzilerle Marunîler arasındaki çatışmaların uluslararası bir kriz halini aldığı Lübnan, Mısır Meselesi ile Kırım Savaşı arasındaki dönemde İmparatorluğun en önemli dış politika ve beka sorunuydu. Mısır meselesi ve Mehmet Ali Paşa hadiselerine dair Fransa'ya karşı duyulan güvensizliğin izlerinin hala çok taze olduğu bu dönemde Lübnan konusunda da Osmanlı ile Fransa karşı karşıya yer almaktaydı. İmparatorluğun bu konudaki destekçisi yine Britanya'ydı. ${ }^{11}$

Aynı dönemde ABD’yle kurulan ilişkinin ve ABD’den sağlanan desteğin de çıkış noktası benzerdir. Zira ABD'nin takip ettiği dünya politikası Osmanlı İmparatorluğu'nun aleyhinde değildi. ${ }^{12}$ $\mathrm{Bu}$ durum Tanzimat ricali için hayati ehemmiyetteydi. Örneğin, 1852 yılında Dışişleri Bakanı Fuat Paşa, ABD mukim elçisi Brown’a, iki ülke arası ilişkilerin gelişmesinden duyulan memnuniyeti dile getirirken, Osmanlı İmparatorluğu’nun Avrupa'nın çeşitli devletleriyle birçok kereler savaştı̆̆ını ama ABD’yle ilişkilerinin dostane kaldığını, bunun ABD’nin uzaklığından veya savaşacak gücü olmamasından değil, takip ettiği barışçıl politikadan kaynaklandığını söylemekteydi. ${ }^{13}$ Görünen o ki ABD'nin geleneksel, "karışmama" (non-involvement) politikası Osmanlı ricalinde güven uyandırmaktaydı. ${ }^{14}$ Tanzimat döneminde ABD’nin asıl amacı ve odak noktası Osmanlı İmparatorluğuyla olan ticareti geliştirmekti. ${ }^{15}$ Osmanlı’nın politikası ise dönemin dış politika anlayışına uygun olarak İmparatorluğun bekası ve yeniden yapılandırılması için güçlü ve modern müttefikleri çoğaltıp çeşitlendirmekti. Bu durum ABD'yi Osmanlı ricalinin gözünde modernleşme hususunda destek alınabilecek alternatif bir merkez haline getirmekteydi.

9 Ibid.

10 İleride aynı prensip sebebiyle Osmanlı İmparatorluğu'nun modernleşme politikasındaki ortağı Prusya- Almanya olacaktır.

11 Cebel-i Lübnan Meselesi ile ilgili ayrıntılı bilgi için bkz. Sarıalioğlu, Stratford Canning, ss. 263-304.

12 ABD’nin 19. yüzyılda Osmanlı İmparatorluğu’na ve Doğu Sorunu'na dair izlediği dış politika hususundaki özet değerlendirme için bkz. Çağrı Erhan, Türk-Amerikan İlişkilerinin Tarihsel Kökenleri, Ankara, İmge Yayınevi, 2001, ss. 244248.

13 NARA, M-46, Brown'dan Charles Conrad'a, 11 Aralık 1852.

14 Erhan, Türk-Amerikan, s. 149.

15 NARA, M-46, Marsh'tan Claytan'a, 8 Mayıs 1850. 


\section{Askeri Reformlar ve Teknoloji Transferi}

Osmanlı modernleşme tarihinin hemen her döneminde olduğu gibi, Tanzimat döneminde de ordunun modernleşmesi İmparatorluğun öncelikli gündem maddelerinden birini oluşturmuştur. 18. yüzyıldan itibaren Osmanlı İmparatorluğu askeri modernleşme hamlelerini hızlandırmış ve bu hususta Avrupa devletlerinden destek almaktan geri durmamıştır. Destek alınacak ülkeyi belirlerken uygulanan dış politikada uyum prensibi Tanzimat Dönemi'nin stratejik ortağı olarak -18. yüzyıldaki Fransa’nın aksine- Britanya'yı öne çıkarmıştır. ${ }^{16}$

Mısır Krizinin damgasını vurduğu 1833-1841 arası dönemde Britanya için Osmanlı askeri modernleşmesi birincil önemdeki konular arasındadır ve ilk etapta Britanyalı subaylar aracılığıyla Osmanlı ordu ve donanmasının modernleşmesine ağırlık verilmiştir. ${ }^{17}$ Tanzimat Fermanı́nın ilanının ardından ise Osmanlı askeri sisteminin modernleşmesi çok daha etraflı ve sistematik bir projenin içerisinde yerini almıştır. Bu açıdan dönemin İstanbul Büyükelçisi Ponsonby’nin Osmanlı ordusunun modernleşmesine dair hazırladığı, askeri okulların kurulması ve Avrupa tarzında eğitim verilmesini de içeren 1841 tarihli raporu önemli bir yer taşımaktadır. ${ }^{18}$

1841'de İstanbul'a atanan büyükelçi de Bâb-1 Âli yöneticileriyle gerçekleştirdiği ilk görüşmeden itibaren, İmparatorluğun modernleşmesi hususunda Osmanlı askeri teşkilatının düzenlenmesinin taşıdığı öneme sürekli vurgu yapmıştır. ${ }^{19}$ Örneğin 1844 yılında Britanya Dışişleri Bakanı Aberdeen düzenli ordunun gerekliliği üzerinde durmakta ve yolladığı talimatla İstanbul'daki büyükelçiden eğitimsiz askerlerin düzensiz yığını yerine küçük düzenli birliklere yönelmeleri konusunda Bâb-ı Âli'yi teşvik etmesini istemekteydi. Aberdeen’e göre, Bâb-ı Âli'nin yapması gereken Avrupa'da yaygın olan askere alım usulleri ile Britanya'daki denizcilerin zorunlu hizmetini örnek almaktı. ${ }^{20} \mathrm{Bu}$ talimatın ardından İstanbul'da yapılan görüşmelere bakıldığında, askeri modernleşme hususunda Britanya-Osmanlı işbirliğinin artmakta olduğu daha net olarak ortaya çıkmaktadır. 1845 yılında İstanbul'daki büyükelçi ile Osmanlı devlet ricali arasındaki görüşmelerde, küçük düzenli birliklerin daha fazla işlerliğe sahip olmasının yanı sıra gereğinden büyük oluşunun yarattığı ekonomik baskıdan dolayı da orduda küçülmeye gidilmesi üzerinde mutabık kalınmıştır. ${ }^{21}$ Osmanlı İmparatorluğu’nun düzenli orduya geçiş niyet ve isteğini resmi ağızlardan ifade ettiği bu görüşmelerle eşzamanlı olarak ülkede askerlikle ilgili meydana gelen gelişmelere bakıldığında, karşımıza 1846 tarihli kanunname çıkmaktadır. Kanunnamenin hazırlanması aşamasında maddeler üzerinde karşılıklı fikir alışverişinin bulunduğuna dair bir belgeye rastlanmamıştır. Fakat kanunnameyle meydana gelen değişikliklerin önemli bir kısmının görüşmelerde altı çizilen konuları içermesi, bu dönemde Britanya'nın askeri modernleşme hususunda ortaklık kurulan ülkelerin başında geldiği değerlendirmemizi destekleyen bir yorum olacaktır.

16 Fatih Yeşil, "Kara Kuvvetlerinde Avrupalı Danışmanlar”, Gültekin Yıldız (der), Osmanlı Askeri Tarihi: Kara, Deniz ve Hava Kuvvetleri 1792-1918, İstanbul, Timaş, 2013, ss. 79-80.

17 Dönmez, Osmanlı Modernleşmesinde, s. 279; Rodkey, Lord Palmerston, Part I, ss. 577-579, 593.

18 Dönmez, Osmanl Modernleșmesinde, ss. 300-310; Bailey, British Policy, s. 190.

19 BOA, I..HR.12-583, 26 C 1257, BOA, HR. SFR.3, 5-61, 7 Eylül 1843.

20 TNA, FO 78/552, No.9, Aberdeen'den Canning'e, 20 Ocak 1844.

21 TNA, FO 78/600, No. 45, Canning'den Aberdeen'e, 17 Ağustos 1845; TNA, FO 78/602, No.245, Canning'den Aberdeen'e, 30 Ekim 1845; TNA, FO 78/602, No.266, Canning'den Aberdeen'e, 19 Kasım 1845; TNA, FO 78/603, No.286, Canning'den Aberdeen'e, 17 Aralık 1845; TNA, FO 78/637, No. 2, Canning'den Aberdeen'e, 9 Ocak 1846. 
Osmanlı İmparatorluğu’nda Yeniçeri Ocağı’nın kaldırılmasıyla beraber uygulanmaya başlanan askere alım yöntemleri oldukça sert ve kaba bir nitelik arz etmekteydi. Hükümet, ihtiyaç duyuldukça Padişahın emriyle valilerden, bölgelerinden asker toplayıp göndermelerini istemekteydi. $\mathrm{Bu}$ iş için görevlendirilen memurlar da gittikleri yerin ileri gelenleriyle birlikte istenen sayıdaki erkekleri Müslüman halk arasından herhangi bir prensibe bağlı olmadan zorla seçmekteydi. Eşit haklara dayanmayan ve kayırmalara elverişli olan bu yöntem bir taraftan hoşnutsuzlukları gün geçtikçe artırmaktayken, diğer taraftan da Tanzimat Fermanı́nın öngördüğü eşitlik, hiç kimseye zulüm ve baskı yapılmaması, herkesin hak ve vazifesini önceden bilmesi gibi ilkelere aykırı oluşuyla da eleştirilerin odağı olmaktaydı. ${ }^{22} \mathrm{Bu}$ yüzden 1846 Kanunnamesi'ndeki ${ }^{23}$ temel amaçlardan biri askere alım usullerinde düzenlemeye gitmekti. Buna göre askere almada kura usulü getirilerek askere alma kurala bağlanmış oldu. Her yıl bahar (Mart) aylarında askerlik çağına gelmiş olan Müslüman halk kuraya katılarak askere alınacaktı. Ayrıca Kanunname'de düzenli orduya geçiş süreci gelişmeleri olarak değerlendirilebilecek başka yenilikler de vardı. Osmanlı ülkesinin beş ordu bölgesine ayrılması ve askerliğin beş yıl ile sınırlandırılması, beş yılını dolduran askerlerin terhis edilmesi ve yerlerine bölgenin askerlik çağına gelmiş olan erkek nüfusundan kura usulüyle yeter sayıda alınması, askerlik yaşının 20-25 yaş aralığı olarak belirlenmesi ve subayların üzerlerine sivil görev almaması bunlar arasında sayılabilir. ${ }^{24}$

1847 yılında ise ordunun modernleşmesi konusundaki karşılıklı görüşmelere yeni bir boyut eklenmiştir: Gayrimüslim Osmanlı vatandaşlarının orduda görev alması. Dönemin İstanbul Elçisi Cowley'e gönderilen 13 ve 27 Eylül 1847 tarihli talimatlara göre, Hıristiyanların askerlik hizmetinde görev almalarının hakkıyla tanzim edilmesi, Sultan'ın tüm uyruklarının, eşit hak ve ayrıcalıklara sahip olarak bütünleşmesi yolunda çok büyük ve önemli bir adımdı. Bu adımın atılması İmparatorluğun güvenliğinin temelini oluşturacaktı. Ayrıca yapılacak düzenlemelerde Hıristiyan bir bölüğün bir Müslümanın komutasına verilmesindense Hıristiyan bir bölüğün bir Hıristiyan tarafından komuta edilmesine dikkat edilmeliydi. Hüner, beceri ve bağlılık açısından Müslümanlarla eşit mertebede Hıristiyan askerler yetişene kadar Hıristiyanlardan oluşan ve bir Hıristiyan'ın komutasında olan bölükler Müslüman bir tugay komutanın emrinde olabilirdi; fakat sıralanan meziyetlere sahip Hıristiyan askerler yetiştiğinde ordu içi düzenlemelerde yeniliklere gidilmeliydi. ${ }^{25}$ Ancak bu önerilerin hayata geçeceği zeminin oluşması için Kırım Savaşı’nı beklemek gerekecekti. 1855 yılının Mayıs ayında cizyenin kaldırılması, bundan sonra Hıristiyanların da Müslümanlar gibi askere çağrılması ve Gayrimüslimlerin de Müslümanlar gibi miralaylığa, siyasi ve idari hizmetlerde ise birinci sınıf memuriyetlere kadar yükselebilmesi karara bağlanacaktı. ${ }^{26}$ Ayrıca, Palmerston'dan Cowley’e gönderilen 27 Eylül 1847 tarihli talimat, muharebe dışında yaşanan kayıpların neredeyse muharebe durumuyla aynı olduğunun altını çizmekte ve Türk askerinin kıyafet, levazım, karargâh, beslenme ve tedavi imkânlarının ıslahı hususunu da gündeme getirmekteydi. ${ }^{27}$

22 Musa Çadırcı, “Osmanlı İmparatorluğu’nda Askere Almada Kura Usulüne Geçilmesi (1846 Tarihli Askerlik Kanunu)”, Tülay Ercoşkun (der.), Tanzimat Sürecinde Türkiye: Askerlik, Ankara, İmge, 2008, ss. 68-69; Sarıalioğlu, Stratford Canning, s. 257.

23 Söz konusu kanunnamenin ön çalışmaları 1843 yılında başlamıştır. Bkz. Çadırcı, Osmanlı İmparatorluğu’nda, s. 69.

24 Musa Çadırcı, “Osmanlı Ordusunda Yeni Düzenlemeler (1792-1869)”, Tülay Erçoşkun (der), Tanzimat Sürecinde Türkiye: Askerlik, Ankara, İmge, 2008, s. 105.

25 TNA, FO 78/675, No.229, Palmerston'dan Cowley'e, 13 Eylül 1847; TNA, FO 78/675, No.225, Palmerston'dan Cowley'e, 27 Eylül 1847; Bailey, British Policy, s. 218; Turgut Subaşı, Anglo-Ottoman Relations and the Reform Question in the Early Tanzimat Period 1839-1852: With Special Reference To Reforms Concerning Ottoman Non-Muslims, Yayınlanmamış Doktora Tezi, University of Birmingham, 1995, ss. 182-183.

26 Ufuk Gülsoy, Osmanlı Gayrimüslimlerinin Askerlik Serüveni, İstanbul, Simurg, 2000, ss. 56-58.

27 TNA, FO 78/675, No.229, Palmerston'dan Cowley'ye, 13 Eylül 1847. 
Aslında Britanya'nın üzerinde durduğu tüm bu hususlar düzenli/modern bir orduyu işaret etmekteydi. Tanzimat Dönemi boyunca, İstanbul'da görev yapan Britanya büyükelçileri sık sık Osmanlı İmparatorluğu'nun bekası için modern bir ordunun gerekliliğinin altını çizecek ve bu hususta hem fikir olan Osmanlı hükümeti de giderek artan bir biçimde Britanya’yla işbirliği içinde hareket edecektir. Kırım Savaşı ise söz konusu işbirliğinin zirvesini teşkil edecektir.

Teknoloji transferi konusunda Osmanlı yöneticilerinin tercihleri genellikle stratejik ortakları yönünde olmuştur. Bu bağlamda Britanya'nın Osmanlı modernleşmesine teknoloji transferi vasıtasıyla da önemli katkılar sağladığını görmekteyiz. Bu hususta öne çıkan alan tahmin edilebileceği üzere denizcilik ve donanmanın modernleşmesidir. Bu amaçla Tanzimat yıllarında Britanya'yla birçok kez vapur, ticaret gemisi inşa ettirilmesi ve buralarda kullanılacak olan teçhizatın sağlanması konusunda işbirliğine gidilmiştir. ${ }^{28}$ Örneğin, 1842 yılında Londra'dan vapur ve gerekli tüm teçhizat temin edilmiştir. ${ }^{29} \mathrm{Bu}$ işbirliği sadece vapur ve gerekli teçhizatın alımıyla da sınırlı kalmamıştır. Denizcilik hususunda yetişmiş personel sıkıntısı yaşayan İmparatorluğun daha önce de Avrupa'ya görevli gönderdiği ancak beklenen faydayı sağlayamadığı bilinen bir gerçekliktir. Bu duruma bir çare olarak 1842 yılında Londra büyükelçisi Mehmed Emin Âli Paşa’nın kontrolü altında eğitim almak üzere personel gönderilmesi planlanmıştır. Ayrıca aynı sene donanma için gerekli üç nefer mühendis ve dört nefer mimarın yanı sıra -demir topun tunç toptan daha kullanışlı ve iyi olması sebebiyle- demir isagasını (kalıba dökme) öğrenmek için de Londra’ya, Tophane-i Amire’den görevli gönderilmesine karar verilmiştir. ${ }^{30}$

Ayrıca aynı dönemde Osmanlı İmparatorluğu'nda mevcut olan vapur-1 hümayunların tamir ve bakım işlemleri için İstanbul'da bir demir fabrikasının kurulmasına karar verilmiş ve bu hususta gerekli teçhizat ${ }^{31}$ ile bu konulara vakıf mühendis desteği için de Britanya'ya başvurulmuştur. ${ }^{32}$ Denizciliğin yanı sıra, top imali ${ }^{33}$ ve Baruthane-i Amire için gereken alet edevatın alımında da Britanya ön plana çıkmaktadır. ${ }^{34} 1846$ yılına gelindiğinde ise, Osmanlı İmparatorluğu’nun İngiliz tarzı döküm fırınları ithal ederek Tophane-i Amire’yi Britanya desteğiyle modern bir görünüme kavuşturduğu görülmektedir. ${ }^{35}$

Teknoloji transferi konusunda Osmanlı İmparatorluğu’nun Britanya'nın yanı sıra ABD'yle de ortaklık kurduğunu görmekteyiz. ABD’yle kurulan teknoloji transferi ilişkisinde de denizcilik ve donanmayı ilgilendiren hususlar öne çıkmaktadır. Bu hususta Osmanlı yöneticilerinin akıllarına ABD'nin gelmesi ilk kez Navarin Felakati'nin (1827) ardından olmuştur. Britanya, Rusya ve Fransa filoları tarafından Osmanlı-Mısır donanmasının yok edilmesinin ardından donanmanın yeniden inşa edilmesi sürecinde zamanın en ileri tekniklerini kullanarak savaş gemileri yapan $\mathrm{ABD}$, dış politikadaki durum göz önüne alındığında destek alınabilecek neredeyse tek seçenek olarak belirmiştir. ${ }^{36}$ Ardından,

28 BOA, HR. SFR.3, 2-39, 25 Ağustos 1842; BOA, HR. SFR.3, 2-67, 29 Eylül 1842; BOA, HR. SFR.3, 2-75, 17 Ekim 1842; BOA, HR. SFR.3, 3-3, 09 Kasim 1842; BOA, HR. SFR.3, 4-70, 5 Mayıs 1843; BOA, HR. SFR.3, 8-96, 10 Temmuz 1844.

29 BOA, İ.MSM.,15-340, 25 R 1258.

30 Ibid; Sarıalioğlu, Stratford Canning, ss. 263-264.

31 BOA, HR. SFR. 3, , 2-75, 17 Ekim 1842; BOA, I..MSM.,2-71, 14 Ekim 1842; BOA, İ.MSM.,24-611, 06 Ra 1259.

32 BOA, HR. SFR. 3, 4-79, 25 Mayis 1843.

33 BOA, HR. SFR. 3, 3-3, 09 Kasim 1842.

34 BOA, HR. SFR. 3, 3-17, 14 Aralık 1842; BOA, HR. SFR. 3, 4-5, 18 Ocak 1843; Sarıalioğlu, Stratford Canning, ss.263-264.

35 Fatih Tetik ve Serdar Soyluer, "Silah İthalatı ve Kara Harp Sanayii”, Gültekin Yıldız (der.), Osmanlı Askeri Tarihi: Kara, Deniz ve Hava Kuvvetler 1792-1918, İstanbul, Timaş, 2013, s.101.

36 Çağrı Erhan, “Osmanlı-Amerikan İlişkilerinin Başlangıcında Temel Faktörler”, Çağdaş Türk Diplomasisi: 200 yıllık Süreç, 
II. Mahmud döneminde, gemi inşası için Osmanlı tersanesinde görevlendirilen ABD’li uzmanlara rastlamaktayız. Mr. Rhodes ve Mr. Reeves adındaki söz konusu uzmanlar Tanzimat'ın ilanını takiben Osmanlı tersanelerinde gemi mühendisi olarak çalışmaya devam etmiş, 1841 yılı içerisinde görevlerini tamamlayıp ülkelerine dönmüşlerdir. ${ }^{37}$

1844 yılında ABD’nin İstanbul'daki temsilcisi Carr, Serasker Rıza Paşa' ya yeni icat edilmiş tüfek ve tabancaları göstermiş ve daha sonra ABD Hükümeti Paşa'nın beğendiği silahlardan kendisine birer örnek yollamıştır. ${ }^{38}$ Ayrıca o sırada Çanakkale Boğazı’nda Karadeniz’e geçiş izni bekleyen Pylmouth adlı ABD gemisinin ve gemide bulunan askeri malzemenin Rıza Paşa ve o sırada İstanbul Müşiri olan Reşid Paşa ile beraber incelenmesi de konumuz açısından önem taşımaktadır. ${ }^{39}$ Bunun hemen ardından eklenebilecek bir nokta da 1846 yılında Osmanlı İmparatorluğu'nun tersanede çalışan genç ustalardan bazılarını ABD tersanelerinde yeni teknikleri öğrenmek üzere ABD'ye yollamaya karar vermesidir. $^{40}$

1850’li yıllarda Osmanlı İmparatorluğu ile ABD arasındaki reform dayanışması ikili diplomatik ilişkilerin gelişimine paralel olarak artmıştır. Bu noktada, aynı zamanda iki ülke arası ilişkilerde bazı sorunların çıkmasına da sebep olan Macar mültecileri probleminin ve beraberinde getirdiği uluslararası konjonktürün önemi yadsınamaz. ${ }^{41} 1849$ yılında Macar mültecileri probleminden ötürü Osmanlı İmparatorluğu'nun Rusya ve Avusturya ile ilişkileri gerildiğinde, dönemin ABD Elçisi Brown'un Bâb-ı Âli'ye gelerek Hükümeti adına Macar mültecilere gösterilen yakın alakadan dolayı Sultan’a, Sadrazam’a ve Dışişleri Bakanı’na saygılarını sunduğunu belirtmiş ve Rusya ve Avusturya'dan siyasi mülteciler nedeniyle bir saldırı gelmesi halinde, ABD donanmasının, Osmanlı İmparatorluğu'na yardım etmesi emrinin verildiğini bildirmiştir. ${ }^{42}$

1850 yılında İstanbul’a atanan yeni mukim Elçi George P. Marsh ile ikili ilişkilerin ilerlemesine dair kararlılık bir kez daha kendini göstermiştir. Bu açıdan 11 Mart 1850'de Çırağan Sarayında Padişahın huzuruna çıkan Marsh’ın “Türk İmparatorluğu’nun yapılmakta olan reformlar sayesinde medeni dünya ülkeleri içerisinde hızla yükselmekte olduğunu görmekten büyük mutluluk duyduğunu"³ dile getirerek söze başlaması anlamlıdır. Zira, yeni Elçi Marsh, görev süresindeki ana hedefini “ABD-Osmanlı İmparatorluğu arasındaki dostluk ve ticareti attırmak ve ABD'yi Osmanlı'ya tanıtarak Osmanlı'nın ABD'den 'alabileceklerinin' daha iyi görülebilmesini sağlamak" "44 olarak tanımlamaktadır. Marsh’’n bu çalışmalarının neticesinde Emin Bey adında binbaşı rütbesindeki bir deniz subayının ABD'ye gönderilmesine karar verilmiştir. Binbaşı Emin Bey, ABD’deki tersaneleri, dokları, donanma üslerini ve savaş gemilerini gezip incelemekle görevlendirilmiştir. Bâb-1 Âli ayrıca Emin Bey'den ABD'nin ulusal kaynakları, sanayisi ve kamuoyu hakkında bir rapor hazırlamasını istemiştir. ${ }^{45}$ Emin Bey'in ABD ziyareti hem ABD-Osmanlı İmparatorluğu arasındaki diplomatik

Ankara, TTK, 1999, ss. 31-32.

37 NARA, M-46, Marsh'dan Webster'a, 7 Ocak 1851.

38 NARA, M-46, Carr'dan Henry'e, 23 Ağustos 1844; NARA, M-46, Carr'dan Rıza Paşa'ya, 22 Kasım 1844.

39 NARA, M-46, Carr'dan Henry'e, 23 Ağustos 1844.

40 NARA, M-46 Brown'dan Buchanan'a, 7 Şubat 1846; NARA, M-46, Brown'dan Buchanan'a, 27 Mayıs 1846.

41 ABD'nin Macar mültecileri hususunda izlediği politikaya dair ayrıntılı bilgi için bkz. Erhan, Türk-Amerikan, ss. 240-244.

42 NARA, M-46, Brown'dan Clayton'a, 17 Ağustos 1849.

43 NARA, M-46, Marsh'dan Clayton'a, 14 Mart 1950.

44 NARA, M-46, Marsh'dan Clayton'a, 8 Mayıs 1850.

45 NARA,, M-46, Marsh'dan Clayton'a, 8 Mayıs 1850. 
ilişkiler açısından hem de Osmanlı modernleşmesi açısından önemi haizdir. Bu ziyaret neticesinde iki ülke arası ilişkiler yakınlaşmış ve birbirlerine güvenleri artmış, ABD Elçisinin Sultan ve İstanbul'daki devlet ricaliyle ilişkileri, Britanyalıları dahi kıskandıracak derecede derinleşmiştir. ${ }^{46}$ Ayrıca dönemin Amerikan belgelerinde Osmanlı İmparatorluğu'nun bu ziyaretin ardından ABD'ye mukim elçi göndermeye niyetlendiği belirtilmektedir. ${ }^{47}$ Fakat bunun için 1867 tarihini beklemek gerekecektir.

Anglosakson etkisinin yoğun bir biçimde kendini gösterdiği askeri alanın dışında, ABD’yle tarım alanında kurulan teknoloji transferi ilişkisi de Tanzimat dönemi modernleşme hareketi içerisinde önemli bir yere sahiptir. Osmanlı İmparatorluğu'nun ülkeye Amerikan tipi pamuk kültürü getirterek, yaygın bir biçimde kullanımını teşvik etmesi söz konusu işbirliğinin en önemli ayağını oluşturmaktadır. ${ }^{48} \mathrm{Bu}$ dönemde Osmanlı İmparatorluğu pamuk üretimine ve üretim şartlarının iyileştirilmesine büyük önem vermekteydi. Üretimin iyileştirilmesi için, Osmanlı İmparatorluğu’nun pamuk üretilen bölgelerinden seçilen kişilere pamuk işletme tahsili aldırarak, gerekli harcırah ve tohum itasıyla mahallerine geri gönderme uygulamasına başvurulmaktayd ${ }_{1}{ }^{49} \mathrm{Bu}$ hususta devlet ricalinin rol model olarak belirlediği ülkelerin başında ise $\mathrm{ABD}$ gelmekteydi. Pamuk ekimi işiyle ilgili ABD'den gelen uzmanlar doğrudan Padişahın huzuruna kabul ediliyordu. Padişah bizzat gelen ekip tarafından bilgilendiriliyordu. ${ }^{50}$ Haziran 1847 tarihinde Washington'a yolladığı bir raporda ABD Elçisi Carr; Sultan'ın reform çabaları içerisinde, tarım alanındaki üretim şartlarının iyileştirilmesinin baş sıralarda yer işgal ettiğini belirtmekte ve bu işin başına ABD'li uzmanların getirilmesini diplomatik bir başarı olarak değerlendirmekteydi. ${ }^{51}$ Dr. Davis ve Dr. Smith, pamuk üretimine katkıda bulunmak amacıyla ABD Başkanı tarafından ${ }^{52}$ üç yıl süresince Sultan'ın hizmetine verilmişlerdi. ${ }^{53}$ ABD Elçisiyle yaptığı görüşmede, çalışmakta olduğu mevki itibariyle Bâb-1 Âli’ye çok yararlı olduğu kanısında olduğunu belirten Dr. Smith de Carr gibi, bu vesileyle Türk hükümetinin memurlarıyla ilişkilerinin tatmin edici düzeye ulaştığının altını çizerek ABD’nin modernleşme vasıtasıyla kazandığı artı değere işaret etmekteydi. ${ }^{54}$

Her ne kadar sonuçsuz bir girişim olarak kalmışsa da Osmanlı İmparatorluğu'na telgrafı tanıtan da ABD olmuştur. ABD'li Profesör Samuel Morse'un ürettiği telgraf 1848 yılında Padişah Abdülmecid'e gösterilmiş ve bu yeni icattan oldukça etkilenen Padişah Profesöre bir sertifika ve nişan vermişti. ${ }^{55}$ Fakat dönemin şartlarından ötürü daha fazla yol alınamayan bu girişim neticesiz kalacak ve bilindiği üzere Osmanlı İmparatorluğu Kırım Savaşı döneminde Britanya vasıtasıyla telgraf teknolojisine sahip olacaktır.

46 Bkz. NARA, M-46, Reşid Paşa'dan Marsh'a, 6 Ocak 1851; NARA,, M-46, Bahriye Nazırından Marsh'a, 4 Ocak 1851; NARA, M-46, Marsh'dan Milland Fillmoe'ya, 4 Ağustos 1851. Dönemin ABD Elçisinin Washington’a yolladığı rapora göre Emin Bey'in ABD ziyareti ve söz konusu ziyaret sebebiyle ABD Elçiliğine İstanbul'da gösterilen teveccüh Britanya Elçiliği tarafından dahi kıskançlıkla izlenmiştir. Bkz. NARA, M-46, Brown'dan Webster’a, 24 Temmuz 1851.

47 NARA, M-46, Brown'dan Webster'a, 14 Haziran 1951. Osmanlı İmparatorluğu ABD’nde ilk defa 1867 yllında büyükelçilik açacaktır. Bkz. Erhan, Türk-Amerikan, ss.152-160.

48 Erhan, Türk-Amerikan, s. 255.

49 BOA, C.IKTS.,37-1805, 21 Ca 1264.

50 BOA, İ.HR.37-1725, $15 \mathrm{Za} \mathrm{1262;} \mathrm{BOA,} \mathrm{İ.HR.37-1728,} 15 \mathrm{Za} 1262$.

51 NARA, M-46, Carr'dan Dış İşleri Bakanlığı'na, 6 Haziran 1847.

52 NARA, M-46, Carr'dan Buchanan'a, 24 Ekim 1848.

53 NARA, M-46, Brown'dan Clayton'a, 14 Ocak 1850.

54 NARA, M-46, Carr'dan Buchanan'a, 24 Ekim 1848.

55 NARA, M-46, Carr'dan Samuel Morse'a, 23 Ekim 1848. 
Teknoloji transferinde son olarak değinilmesi gereken nokta ise Osmanlı İmparatorluğu'nun inşa etmekte olduğu çuha (yün kumaş) fabrikası ${ }^{56}$ için gerekli teçhizatı da Britanya'dan temin ettiğidir. ${ }^{57}$

\section{Mali Reformlar}

Her dönemde olduğu gibi Tanzimat döneminde de Osmanlı ricali için devletin güvenliğinin ardından gelen en önemli konu devletin finansmanı meselesi olmuştur. Osmanlı́nın modernleş(tiril)mesi meselesini dış politikasının temel prensiplerinden biri haline getiren Britanya da devletin ve reformun finansmanı meselesine büyük önem vermiştir. Britanya; Osmanlı İmparatorluğu’nun bağımsızlığını ve toprak bütünlüğünü koruma prensibini resmi bir politika dâhilinde takip etmeye başladığı dönemden itibaren ekonomi-politik konusunda girişilecek reform hamlelerinde Osmanlı ricali ile işbirliği ve temas içerisinde olmuştur. Örneğin, Tanzimat'ın hemen öncesinde, evvela Britanya ve daha sonra birçok devletle imzalanan 1838 Balta Limanı Sözleşmesiyle yed-i vahid ${ }^{58}$ sisteminin terkedilerek tekel uygulamasına son verilmesi bu ortak çabalardan biri olarak değerlendirilebilir. Zira, Palmerston tekel sisteminden vazgeçilmesi durumunda İmparatorluk gelirlerinin artacağını iddia ediyor, İmparatorluğun refahı için tekel sisteminin tamamen terk edilip serbest ticaret uygulamasının getirilmesini istiyordu..$^{59}$

Tanzimat'ın ekonomik reform hareketi ise öncelikli olarak vergi reformu üzerine kurulmuştu. Tanzimat Fermanı'yla birlikte Osmanlı İmparatorluğu'ndaki vergi sistemi ve vergi toplama usulleri değişmişti. Osmanlı yöneticileri iltizam sisteminin doğurduğu zararlardan kurtulma arzularını metinde açıkça belirtmişler ve bu usulün kaldırılacağını ilan etmişlerdi. ${ }^{60}$ Ferman’n ilanını takiben bu vaat gerçekleştirildi. İltizam usulü kaldırıldı ve vergi tahsil işleri birer devlet memuru olan muhassıllara verildi. Ancak muhassıllar basit birer vergi tahsildarı değillerdi. Bunlar Tanzimat'ı mali açıdan uygulamakla yükümlüydüler. Atandıkları bölgeye gidip oradaki vergi olanaklarını araştırıp vergi miktarlarını yeniden belirlemek ve vergileri tekrardan hak ve adalet ilkelerine uygun bir biçimde saptamak gibi mühim görevleri vardı. ${ }^{61}$ Kısacası Tanzimat'in vergi sisteminin başarısı muhassılların başarı ve süratine bağlanmış durumdayd ${ }^{62}$ ve zaman isteyen bu işin yanı sıra devlet gelirlerinin kaybolmaması meselesi de hayati bir önem taşımaktayd $1 .{ }^{63} \mathrm{Bu}$ zorluklara ek olarak vergi tespit ve takdirinde yapılan yanlışlıklar ve haksızlıklara muhassılların bilgisizlikleri ve yetersizlikleri de eklenince yeni sistem işlemez oldu ve 1842 'de Reşit Paşa'nın sadrazamlıktan uzaklaştırılmasını

56 İncelenen belgede fabrikanın nerede inşa edildiğine dair bir bilgi bulunmamaktadır. Fakat konuyla ilgili yapılan araştırmalardan bahsi geçen fabrikanın İzmit Çuha Fabrikası olduğu anlaşılmaktadır. bkz. Mustafa Kurt et al., "19. Yüzyılda Osmanlı Sanayileşmesi Sürecinde Kurulan Devlet Fabrikaları: Bir Envanter Çalışması”, OTAM, No.40, 2016, s. 257.

57 BOA, HR. SFR. 3, 4-59, 25 Nisan 1843.

58 19. yüzyılın ortalarına kadar Osmanlı İmparatorluğu’ndaki ticari anlayışın genel prensiplerinden biri olan ve tekel anlamına gelen yed-i vâhid, bir kazanın ahalisinin, mahsullerini diledikleri gibi tüccara satmalarına ruhsat vermeyip hükümet tarafından tamamıyla ahz olunarak bir elden/tek elden üçüncü kişilere satılmasını salık veren sistemdir. Bkz. Mübahat Kütükoğlu, Balta Limanína Giden Yol Osmanl-İngiliz İktisadî Münasebetleri (1580-1850), Ankara, TTK. 2013, s. 199.

59 Webster, The Foreign Policy, Cilt. II, s. 540.

60 Nadir Özbek, İmparatorluğun Bedeli: Osmanlida Vergi, Siyaset ve Toplumsal Adalet (1839-1908), İstanbul, Boğaziçi Üniversitesi Yayınevi, 2015, s. 87.

61 Yavuz Cezar, Osmanlı Maliyesinde Bunalım ve Değişim Dönemi(XVIII.yydan Tanzimat’a Mali Tarih), İstanbul, Alan Yayıncilık, 1986, s. 282, 306.

62 Cezar, Osmanl Maliyesinde, s. 282.

63 Halil İnalcık, Osmanlı İmparatorluğu: Toplum ve Ekonomi, İstanbul, Eren Yayınları, 1993, s. 366. 
takiben vergi sisteminde eskiye dönüldü. ${ }^{64}$ Britanya hükümeti bu tarihten itibaren, Osmanlı mali sistemini modernleştirme politikasını Tanzimat Fermanı'nda önerilen vergi sisteminin hayata geçirilmesini/yeniden uygulamaya koyulmasını sağlamak üzerine kurmuştur. ${ }^{65}$ Tanzimat' in vergi politikasının yeniden uygulamaya konulması; vergi sisteminde eskiye dönülmesini ve Tanzimat'in mimarı Reşid Paşa'nın iktidardan uzaklaştırılmasını bir bütün olarak Osmanlı modernleşmesinin reddedilmesi olarak değerlendiren Britanya için hayati önem taşımaktayd.$^{66} \mathrm{Bu}$ sebeple Britanya vergi meselesini, Osmanlı İmparatorluğu’nun hayatta kalmak ve Britanya’nın desteğini almak için Tanzimat Fermanı'nda verdiği sözleri yerine getirmesi gerektiği iddiasıyla, Bâb-ı Âli üzerinde sık sık bir baskı aracı olarak kullanmıştır. ${ }^{67}$

Aslında Britanya; yeni sistemin, rüşvet ve görevlilerin cehaletinden dolayı ciddi bir gelir kaybına sebep olduğunun ve mali ihtiyaçların hiç olmadığı kadar aciliyet kesp ettiğinin farkındaydı. Fakat tüm bu sorunlara rağmen hem devletin gelir kaynakları hem de mülk sahipleri açısından daha avantajlı olduğunu iddia ettiği yeni vergi sisteminin tekrar uygulamaya koyulmasından başka çare olmadığını düşünmekteydi. ${ }^{68}$ Ayrıca, vergi sistemindeki değişim, İmparatorluğun mali yapısına getireceği katkının yanı sıra Müslüman-Gayrimüslim eşitliği açısından da önem taşımaktaydı. ${ }^{69}$ Britanya’ya göre Tanzimat Fermanı Sultan’ın tebaası arasındaki ayrımları ortadan kaldırmayı vadetmişken vergi sisteminde Tanzimat öncesine dönülmesi her ne kadar düzeltmeler yapılsa da önceki zamanlarda sık sık karşılaşılan haraç kesme, zorbalık ve şiddetli baskı uygulamalarını geri getirecekti. ${ }^{70}$

Britanya’nın Osmanlı’nın mali sistemi üzerindeki modernleş(tir)me çabaları sadece vergi sistemine odaklanmamış, aynı zamanda bir bütün olarak maliyenin ıslahı mevzusu da modernleşme hususunda iki ülke yetkilileri arasında yapılan görüşmelerde sıklıkla gündeme gelmiştir. Örneğin İstanbul'daki büyükelçi Bâb-1 Âli ile mevcut idari ve mali sistemin, İmparatorluğun kaynakları üzerindeki ağırlı̆̆ının ve bu hususların reforma muhtaç oluşunun altını çizen birçok görüşme yapmıştır. $^{71}$ Tedavüldeki paranın sslah edilmesinden ziyade kamu görevlilerinin yolsuzluklarının ortadan kaldırılması gerekliliği de bu görüşmelerde sık sık tekrar edilmiştir. ${ }^{72}$ Ayrıca, Britanya tarafından kötü yönetimin hazine üzerindeki baskısı ve yolsuzluğun önüne geçilmesi gibi önerilerin yanı sıra adil maaşların düzenli ödenmesi ve kamu görevlilerinin sayısının azaltılması gibi daha somut önerilerin geldiğine de rastlamaktayız. ${ }^{73}$

Mali reform ve yeni ekonomi politikası, kaynak ve yetişmiş insan yetersizliği ile sistemsel dönüşüm sancıları gibi sebeplerin de etkisiyle Tanzimat'in en sancılı konularından biriydi. Canning'in İstanbul'daki görev yılları boyunca, gerek Osmanlı yöneticilerine gerek Londra’ya sık sık ve ısrarla

64 Necdet Sakaoğlu, Nuri Akbayar, Avrupalılaşmanın Yol Haritası ve Sultan Abdülmecid, İstanbul, Denizbank, 2001, s.283.

65 TNA, FO 78/475, No. 13, Canning'den Aberdeen'e, 11 Şubat 1842; TNA, FO 78/475, Canning'den Aberdeen'e, 16 Şubat 1842; TNA, FO 78/475, No.23, Canning'den Aberdeen'e, 26 Şubat 1842.

66 TNA, FO 78/475, No.13, Canning'den Aberdeen'e, 11 Şubat 1842; TNA, FO 78/475, Canning'den Aberdeen'e, 16 Şubat 1842.

67 TNA, FO 78/475, No.13, Canning'den Aberdeen'e, 11 Şubat 1842.

68 TNA, FO 78/475, No.21, Canning'den Aberdeen'e, 16 Şubat 1842.

69 Bailey, British Policy, s. 218.

70 TNA, FO 78/475, No.21, Canning'den Aberdeen'e, 16 Şubat 1842.

71 TNA, FO 78/564, No.293, Canning'den Aberdeen'e, 28 Aralık 1844; TNA, FO 78/637, No.2, Canning'den Aberdeen'e, 9 Ocak 1846.

72 TNA, FO 78/552, No.9, Aberdeen'den Canning'e, 20 Ocak 1844.

73 TNA, FO 78/645,No. 145, Wellesley ‘den Palmerston’a, 29 Kasım 1846. 
göndermeye devam ettiği, temelde yukarıdaki görüşleri içeren raporlarına rağmen Tanzimat yılları içerisinde mali dönüşüm konusunda ne Canning'in ne Tanzimatçıların beklediği ilerleme kaydedilebildi ve mali dönüşüm ve vergi konusundaki beklentiler Islahat Fermanı́nda da kendine yer buldu. ${ }^{74}$

\section{Hukuki-Idari Reformlar}

Hukuk alanında gerçekleşen reformlara baktığımızda karşımıza ilk etapta, din değiştirme (irtidâdmürted) sebebiyle idam uygulamasının kaldırılması (Mart 1844), ${ }^{75}$ Hıristiyanların şahitliğinin geçerli olduğu karma mahkemelerin tesisi $(1848)^{76}$ ve mahbeslerde işkence uygulamasının yasaklanması (Mayıs 1844)77 gibi mühim değişimler çıkmaktadır. Bu değişimlerin ortak özelliği ise münferit hadiselerin Britanya diplomasisinin de etkisiyle birer hukuk reformu halini almasıdır. Örneğin, İslamiyet'te dinden dönenlere bir diğer ifadeyle Müslümanken veya Müslümanlığı kabul ettikten sonra Hıristiyan olanlara uygulanan idam cezası kuralının kaldırılması Avakim isimli bir gencin Müslüman olduktan sonra tekrardan kendi dinine dönmesi sonucu idam edilişi üzerine Britanya'nın İstanbul'daki büyükelçisinin çıkardığı diplomatik krizin bir neticesidir. ${ }^{78}$ Benzer bir biçimde, Osmanlı hukuk sistemi içerisinde gayrimüslimlerin şahitliğinin bir Müslümanın şahitliği karşısında geçerli sayılabilmesinde de Canning'in rolü olmuştur. ${ }^{79}$ Süreçte büyükelçinin tarafları gayrimüslim ve Müslüman olan iki ayrı ceza hukuku davası üzerinden yürüttüğü diplomatik baskı etkindir. Mahbeslerde işkencenin önlenmesi süreci ise, Britanya'nın İzmir Konsolosu Brant'a İzmir'de mukim Britanya tebaası tarafından bu yönde verilen şikâyet dilekçeleriyle başlamıştır. ${ }^{80}$ Britanya tüm bu münferit hadiselerde, Osmanlı İmparatorluğu'nun ilgili kural ve uygulamalarının Tanzimat Fermanı'nın eşitlik ve adalet vaadine aykırı olduğunu ve Avrupa'ya hakaret içerdiğini ileri sürerek, Bâb-1 Âli üzerinde baskı kurma yoluna gitmiştir. $^{81}$

Mahbeslerde işkence uygulamasının önlenmesinin ardından Britanya’nın bu husustaki çabaları topyekun bir hapishane reformuna yönelmiştir. Suçlu ve sanıkların gördüğ̈ muameleden, Osmanlı hapishanelerinin koşullarına ve hatta modern ceza ve hapsedilme felsefesi ve uygulamalarının İmparatorlukta geçerlilik kazanmasına doğru genişleyen cezalandırılma/kapatılma rejiminin modernleşmesinde Britanya'nın bu husustaki çabaları önemli bir yer işgal etmektedir. Bu konuda özellikle dönemin Britanya büyükelçisi Cannign'in 1851'de hazırladı̆ğ "Improvement of Prisons in

74 Ayrıntılı bilgi için bkz. Sarıalioğlu, Stratford Canning, s.186-197.

75 BOA, I.MSM.,63-1830; TNA, FO 78/555, Canning'den Aberdeen'e, 23 Mart 1844; Poole, The Life of, Cilt II, s.98; Subaşı, Anglo-Ottoman, s.268.

76 TNA, FO 78/643, No.41, Wellesley'den Palmerston'a, 4 Eylül 1846; TNA, FO 78/644, No.82, Wellesley'den Palmerston'a, 14 Ekim 1846; Allan Cunningham, "Stratford Canning and the Tanzimat", Edward Ingram (der.), Eastern Questions in the Nineteenth Century, Londra, Frank Cass, 1993, s.124; Gülnihal Bozkurt, Batı Hukukunun Türkiye'de Benimsenmesi (1939-1939), Ankara, TTK, 2010, s.156.

77 TNA, FO 78/557, No.90, Canning'den Aberdeen'e, 17 Mayıs 1844.

78 Konu ile ilgili ayrıntılı bilgi için bkz. Poole, The Life of, Cilt II, s. 89-99; Subaşı, Anglo-Ottoman, ss. 231-273; Turgut Subaşı, "The Apostasy Question in the Contex of Anglo-Ottoman Relations, 1843-44”, Middle Eastern Studies, Cilt 38, No 2, Nisan 2002, ss. 1-34; Steven Richmond, The Voice of England in the East: Stratford Canning and Diplomacy With Ottoman Empire, Londra, I.B. Tauris, 2014, ss. 203-235.

79 Bailey, British Policy, s. 213,215.

80 TNA, FO 78/476, No.5, Brant'dan Canning'e, 18 Şubat 1842.

81 Bahsi geçen konularda ayrıntılı bilgi edinmek için bkz. Sarılioğlu, Stratford Canning, ss. 218-254. 
Turkey/Türkiye'deki Hapishanelerin İyileştirilmesi” başlıklı rapor önemli bir rol oynamıştır. ${ }^{82}$ Aslında bu dönemde, Osmanlı'daki suçluların durumuyla sadece Britanya ve Canning ilgilenmemiştir. Mahbeslerde işkencenin önlenmesine dair yukarıda anlatılan gelişmelerin yaşanmasının ardından Fransa'nın da bu hususta girişimleri olmuştur. Örneğin, 1847-1848 yılları civarında Fransız İçişleri Bakanı M. Duchatel, Başbakan M. Guizot tarafından başka bir görevle Balkanlar’a gönderilmiş olan politik ekonomi profesörü M. Blanqui'den Türk mahbeslerinin ekonomi ve disiplin rejimi üzerine bir rapor hazırlamasını talep etmiştir.$^{83}$ Fakat Fransa'nın bu çaba ve girişimlerine rağmen Osmanlı mahbeslerinin modern hapishaneye dönüşmesi sürecinde İmparatorluğun birlikte çalıştığı esas aktör Britanya olmuştur. Hapishane reformu üzerinden yaşanan bu Fransa-Britanya rekabeti ve neticede dönemin stratejik ortağı Britanya'nın ön plana çıkışı da bu çalışmanın temel tezini desteklemektedir.

Tanzimat döneminde Britanya desteğiyle Osmanlı İmparatorluğu’nun gerçekleştirdiği modernleşme hamlelerinden biri de siyah köle ticaretinin yasaklanmasıdır. Britanya'nın bu husustaki ilk girişimi 1812 gibi erken bir tarihte yaşanmıştır. Fakat bu girişimin 1840 'a kadar arkası gelmemiştir. ${ }^{84}$ 1840 yılına gelindiğinde ise gerek Viyana Kongresi gerek ardından gerçekleşen gelişmeler çerçevesinde Britanya için daha etraflı bir politikaya dönüşen köle ticaretinin yasaklanması hedefi, Osmanlı İmparatorluğu ile kurulan diplomatik bağda mühim ve süreklilik arz eden bir unsur olarak yerini almıştır. Bu anlamda, 1840 yılında Palmerston'un İstanbul'daki büyükelçi Ponsonby’e gönderdiği “Osmanlı İmparatorluğu'nun kölelik ve köle ticaretiyle ilgili çağa uygun önlemler almasının sağlanması” yönündeki talimatla ${ }^{85}$ başlatabileceğimiz Britanya diplomatik girişimlerinin temel savları, siyah köle ticaretinin yasaklanmasının "İngiliz politikasının lüzumlarından biri olduğu, şan-ı insaniyetten olan böyle bir amacın gerçekleşmesi için İngiliz milletinin çokça fedakârlıklarda bulunduğu, Sultan'ın adaletinin Avrupa'dan övgüler aldığı bir dönemde Britanya Devletinin müttefik-i kadiminden bu hususta gerekeni yapmasını istemesinin gayet doğal olduğu" ${ }^{\prime 6}$ noktalarında toplanmaktadır. Britanya’nın bu taleplerinin karşısında Osmanlı tarafının amacı ise, İmparatorluk için asıl önemli olan beyaz köle ticaretini (Çerkez ve Gürcü) en azından şimdilik mevzunun dışında bırakarak Britanya'yla kurulan yakın ilişkilerin bozulmamasını sağlamak olmuştur. ${ }^{87}$ Osmanlı İmparatorluğu'nun istediği istisnayı elde ettiği bu görüşmelerin neticesinde, Ocak 1847'de, Basra Körfezi’nde siyah köle ticaretini yasaklayan ferman ortaya çıkmıştır. ${ }^{88}$ Bu fermanı daha sonra, ilk etapta 1853 'te Bağdat Valisi’ne gönderilen benzer bir ferman, ardından da Kırım Savaşı ve Paris Konferansı gibi mühim gelişmelerin gölgesinde şekillenen 1857 tarihli bir başka fermanla Osmanlı İmparatorluğu genelinde siyah köle ticaretinin yasaklanması izlemiştir. ${ }^{89}$

82 Konu ile ilgili ayrıntılı bilgi için bkz. Gültekin Yıldız, Mapushâne Osmanlı Hapishanelerinin Kuruluş Serüveni (18391908), İstanbul, Kitabevi, 2012, s. 110-163; Canning'in “Report on Prisons in Turkey” ismiyle İngiliz arşivine kayıttlı olan ilgili raporu için bkz. TNA, FO 195/364.

83 Yıldı, Mapushâne, ss. 110-111. M. Blanqui'nin Osmanlı hapishanelerine dair misyonu için bkz. Charles Mac Farlane, Turkey and Its Destiny. The Result of Journeys Made in 1847 and 1848 to Examine into the State of That Country, Cilt II, Philadelphia, Lea and Blanchard, 1850, ss. 216-218.

84 Ehud R. Toledano, Osmanlı Köle Ticareti, çev. Hakan Erdem, İstanbul, Tarih Vakfı Yurt Yayınları, 1994, ss. 77-78.

85 TNA, FO 84/333/37-43 Palmerston'dan Ponsonby'e, 22 Ağustos 1840.

86 BOA, İ.MSM.,29-822, $22 \mathrm{Z} 1262$.

87 Ibid.

88 TNA, FO 84/691/ 50-3, Wellesley'den Palmerston'a, 1 Şubat 1847. Ferman ve Britanya'nın memnuniyetlerini dile getirdiği yazışmalar için bkz. BOA, I.MSM.,29-828, 27 C 1263.

89 Y. Hakan Erdem, “Tanzimat Döneminde Kölelik” Tanzimat: Değişim Sürecinde Osmanlı İmparatorluğu, Halil İnalcık ve Mehmet Seyitdanlığlu (der.), İstanbul, İş Bankası, 2013, s. 132. 
Siyah köle ticaretinin Osmanlı İmparatorluğu'ndaki yasaklanma sürecini bitirmeden önce bu hususta Britanya ve ABD'nin İstanbul'daki elçileri arasında bir nevi mutabakata varılmış olduğunun da altı çizilmelidir. 1846 yılında İstanbul'da, Britanya Büyükelçisi Canning ve ABD mukim Elçisi Brown arasında tarihi öneme sahip bir görüşme gerçekleşmiştir. Bu görüşmede, Osmanlı İmparatorluğu'na dair mühim birçok konunun yanı sıra siyah köle ticareti de iki ülke temsilcilerinin gündeminde yer almıştır. Fakat hemen belirtmek gerekir ki, Osmanlı'daki siyah köle ticaretinin yasaklanması hususunda sadece elçiler arası bir mutabakata varılmıştır. En azından inceleme dönemimiz olan erken Tanzimat yılları için, İstanbul'daki temsilcileri aşan bir gelişmeden -Britanya ve ABD dışişleri bakanlıklarının ortak bir tutum ve politika belirleme girişimlerindenbahsetmemiz mümkün değildir..$^{90}$

Söz konusu görüşme esnasında ele alınan konulardan biri de Protestanlardır. Bilindiği üzere, Osmanlı İmparatorluğu’nda Protestanlık, Britanya diplomasisi ve Amerikan misyonerlerinin işbirliği sayesinde tutunabilmiştir. ${ }^{11} \mathrm{Bu}$ noktada ilginç olan husus, bahsedilen görüşmede, Protestanların millet olarak tanınmasının ele alınan konulardan biri olmasının yanı sıra ABD konsolosluklarının olmadığı yerlerde Britanya konsoloslarının $\mathrm{ABD}$ vatandaşlarını -dolayısıyla misyonerleri- korumaları konusunun da yer almasıdır. ${ }^{92}$ Üstelik siyah köle ticaretinin yasaklanmasından farklı olarak bu husus İstanbul'u aşıp Londra'ya da ulaşmıştır. ${ }^{93}$ Zira, söz konusu görüşme öncesinde Canning, kendisine iletilen bu teklifi merkezine bildirmiş ve bu konuda Aberdeen tarafindan resmi olarak yetkilendirilmiştir. ${ }^{94}$

Aslında Britanya bahsi geçen görüşmeden çok önce Protestanların hukuki durumuna dair çalışmalarına başlamıştı. İmparatorluk içerisinde bir Protestan milleti oluşturarak Fransa ve Rusya gibi hamiliküzerinden güç kazanmakamacıyla, henüz 1840 yılında Kudüs'te bir Protestan mabedi inşası için Bâb-1 Âli'den izin istemişti. ${ }^{95}$ Ancak, 1842'de çıkan izin çeşitli sebeplerle rafa kaldırılmış ve 1845 yılına kadar Osmanlı-Britanya ilişkilerinde Kudüs'te bir Protestan mabedi kurulması birçok görüşmenin temel tartışma konusunu oluşturmuştur. ${ }^{96}$ Bu dönemde bir taraftan Amerikalı misyonerlerin ABD ve Britanya elçilikleriyle temas halinde sürdürdükleri çalışmalar sürerken, bir taraftan da İstanbul'da bulunan Britanya büyükelçileri Bâb-1 Âli nezdindeki baskılarını arttırmışlardır. ${ }^{97}$ Nihayetinde, 10 Eylül 1845'te Osmanlı İmparatorluğu bir fermanla Kudüs'te Protestan kilisesinin inşasına müsaade etmek durumunda kalmıştır. ${ }^{98}$ Kudüs'te bir Protestan mabedi izni alınmasını takiben sonraki adıma geçilmiştir. ABD büyükelçisi Brown'un merkezine yolladığı raporlarda da açık bir biçimde yer aldığı üzere bir sonraki adım Protestanların ayrı bir millet olarak tanınmalarını sağlamaktan başka bir şey değildir. ${ }^{99}$ Bâb-1 Âli’nin mevzunun gelecekte kendisine verebileceği tehlikeleri öngörüp direnmesine

90 NARA, M-46, Brown'dan Buchanan'a, 4 Haziran 1846.

91 İlber Ortaylı, İmparatorluğun En Uzun Yüzyıl, İstanbul, Timaş, 2008, s. 136.

92 NARA, M-46, Brown'dan Buchanan'a, 4 Haziran 1846.

93 TNA, FO 78/592, No.39, Aberdeen'den Canning'e, 5 Nisan 1845,

94 Ibid.

95 Engelhardt, Tanzimat ve Türkiye, çev. Ali Reşad, İstanbul, Kaknüs, 1999 s. 6.

96 BOA, I.MSM.,29-816, 20 Ş 1261. Sürece dair ayrıntılı bilgi için bkz. Subaşı, Anglo-Ottoman, ss. 286-297.

97 TNA, FO 78/644, No.91, Wellesley'den Palmerston'a, 19 Ekim 1846; TNA, FO 78/645, No.104, Wellesley'den Palmerston'a, 2 Kasım 1846; Poole, The Life of, Cilt II, s. 102-103; Subaşı, Anglo-Ottoman, s. 291-293; Erhan, TürkAmerikan, s. 197.

98 TNA, FO 78/601, No.205, Canning'den Aberdeen'e, 3 Eylül 1845; TNA, FO 78-601, No.216, Canning'den Aberdeen'e, 16 Eylül 1845; Poole, The Life of, Cilt II, s.103.

99 NARA, M-46, Brown'dan Buchanan'a, 4 Haziran 1846. 
rağmen Britanya ve ABD’nin çabaları galip gelmiş ve Canning, Amerikan misyonerlerine şükran ifadeleriyle dolu olan bir raporla Palmerston'a -24 Ekim 1850 tarihli- Protestanlara millet statüsü veren fermanı müjdelemiştir. ${ }^{100}$

\section{Eğitim ve Sağlık Alanlarına Dair Reformlar}

Temsilciliklerinin olmadığı yerde ABD vatandaşlarını koruma görevini Britanya konsolosluklarının yüklenmesi vasıtasıyla ortak bir Anglosakson çabasından bahsedebileceğimiz bir diğer alan da eğitimdir. Aslında, teknoloji transferini sağlamak amacıyla Britanya'yla kurulan eğitim bağını bir kenara bırakarak bir bütün olarak Osmanlı eğitim sistemi üzerindeki Britanya etkisine bakıldığında; diğer alanlarda gerçekleşen işbirliğine eğitim alanında rastlamanın mümkün olmadığı görülmektedir. Eğitim konusunda, en azından inceleme dönemimiz açısından, Britanya’nın açtıkları okullar vasıtasıyla Osmanlıdaki eğitim sisteminin modernleşmesine katkıda bulunan Amerikalı misyonerlere verdiği destek dışında önemli bir katkısı olduğunu iddia etmek güçtür. Hatta eğitim hususunda Osmanlı İmparatorluğu'nda vuku bulan bazı çabaların Britanya’yla paylaşılmasına rağmen Britanya'nın, bu hususta diğer konular gibi etkin bir politika takip etmediği söylenebilir. Örneğin 1846 yllında gerçekleşen Âli Efendi'nin Wellesley ile görüşmesinde; dönemin Britanya büyükelçisi eğitim konusundaki reformlar üzerine çalışan komisyonun kurulma çabaları hususunda bilgilendirilmiştir. Fakat merkeze görüşmeyi rapor eden Elçiyi, bu konunun pek heyecanlandırmadığı da yazışmadan anlaşılmaktadır. ${ }^{101}$ Palmerston'un bu dönemde benimsediği ve İstanbul'daki Elçiye gerekli araştırmaları yapması talimatını verdiği, İstanbul'da bir Protestan okul kurma fikrinin hayata geçmesi için de beklemek gerekecektir. ${ }^{102}$ Askeri, mali ve hukuki alandaki Osmanlı reformunu öncelik listesine alan Britanya, Bailey’e göre, Sultan’ın eğitim konusunda giriştiği hamlelerde (1845 ve 1846 yıllarında İmparatorlukta açılabilecek yeni okullar ve yeni eğitim sistemi üzerinde çalışılacak komiteler oluşturulması, bir üniversitenin ve orta dereceli okulların açılması fikri gibi) istikrar sağlayacağına dair pek de umutlu değildir. ${ }^{103}$

Yukarıda belirtildiği üzere, Osmanlı İmparatorluğu'nun modern eğitim sistemine geçiş sürecindeki asıl katkı, Amerikan misyonerlerine aittir. Temel hedefleri bulundukları ülkedeki halkın Protestanlığı benimsemesini sağlamak olan ve faaliyetleri 1810'da kurulan American Board of Commissioners for Foreign Missions tarafından idare edilen misyonerlerin ${ }^{104}$ Osmanlı İmparatorluğu için yarattıkları tehdit ve çıkardıkları sorunların yanı sıra kurdukları okullar vasıtasıyla eğitimde modernleşmeye sağladıkları katkı da yadsınamaz bir gerçektir. Osmanlı İmparatorluğu'nda bulunan ABD diplomatik misyonu da -her ne kadar misyonerlerin faaliyetleri neticesinde Bâb-1 Âli ile arası bozulsa da- bu çabaları bir devlet politikası dâhilinde desteklemiş, ${ }^{105}$ kendi gücünün Bâb-1 Âli nezdinde yetmediği durumlarda da Britanya sefaretinden yardım almıştır. ${ }^{106}$

100 TNA, FO 78-824, No.340, Canning'den Aberdeen'e, 18 Kasım 1850.

101 TNA, FO 78/645, No.145, Wellesley'den Palmerston'a, 29 Kasım 1846.

102 TNA, FO 78/691, No. yok, Palmerston'dan Canning'e, 12 Ekim 1847.

103 Bailey, British Policy, ss. 214-215.

104 Erhan, Türk-Amerikan, ss. 83-87.

105 NARA, M-46, Carr'dan Buchanan'a, 2 Ağustos 1848.

106 Erhan, Türk-Amerikan, s.190-193; Uygur Kocabaşoğlu, Anadolu'daki Amerika, Ankara, İmge, 200, ss. 51-53. 
Osmanlı İmparatorluğu'ndaki ilk Amerikan Okulu (Syrian Protestant College) 1824'te Beyrut'ta açılmıştır. Bu yüksekokul doğa bilimleri ve tıp alanında eğitim vermiştir. 1824'ten 1886'ya kadar sayılarının 400'e ulaştığı Amerikan kurumlarının çoğunlukla 1830 ve 1840 'larda açıldığı bilinmektedir. ${ }^{107}$ Ayrıca bu kurumların bünyelerinde barındırdıkları dispanserler ve hastaneler vasıtasıyla Osmanlı'daki sağlık hizmetlerinin gelişimine verdikleri katkı da bilinmektedir. ${ }^{108}$

$\mathrm{Bu}$ dönemde sağlık alanında gerçekleşen modernleşme hamlelerinde ise Bâb-1 Âli'nin Britanya'yla de yakın bir çalışma içerisinde olduğu görülmektedir. Örneğin, 1840 yılında Palmerston, Dr. Davy önderliğindeki bir grup sağlık görevlisini Osmanlı ordusu içerisinde modern sıhhiye bölümünün oluşumuna yardım etmekle görevlendirmiştir. ${ }^{109}$ Ayrıca söz konusu dönemde Britanya’nın girişimleriyle Osmanlı'daki karantina uygulamasına dair önemli gelişmeler vuku bulmuştur. Tanzimat Fermanı́nın hemen akabinde, büyük güçlerin İstanbul'daki temsilcilerine ek olarak Yunanistan ve Sardunya’nın da desteği ile İstanbul ve temel dış limanlarda, sıhhi ve idari görevlileri olan karantina istasyonları inşa edilmiş ve gerekli düzenlemeler hayata geçirilmiştir. Bu düzenlemeler çerçevesinde İstanbul'da kurulan sağlık idaresinde (board of health) belirli sayıda Avrupalıya da yer verilmiştir. Fakat söz konu kurum, Reşid Paşa’nın yönetimden uzaklaştırılması, yeni idarenin reformları Paşa kadar sahiplenmemesi ve mali sıkıntılar gibi çeşitli sebeplerle kuruluşunun hemen ardından atıl duruma gelmiştir. Bunun üzerine, Britanya İstanbul'daki büyükelçisi vasıtasıyla 1844 yılında, Bâb-1 Âli ile karantina idaresinin düzenlenmesi ve etkin bir biçimde çalışmasının sağlanması için yeniden girişimde bulunmuştur. Dönemin büyük güçlerinin İstanbul'daki temsilcilerinin de dâhil edildiği bu girişiminde; kuruma başkanlık eden Paşa’nın keyfi davranışlarının önlenmesi, idarenin güçlendirilmesi, karantina uygulamasının devamının sağlanması, karantinayla ilgili kararların tamamının basit oy çokluğuyla alınıp bir fermanla tevdi edilerek işlerin çabuk yürümesinin sağlanması gibi talepler gündeme getirilmiştir. ${ }^{110}$ Söz konusu talepler Bâb-1 Âli tarafından hiç vakit kaybetmeden hayata geçirilmiştir. Buna göre Bâb-1 Âli sıhhi, idari ya da karantina bölümlerini ilgilendiren hususlarda olsun kararların basit oy çokluğuyla alınmasına ve şikâyet edilen Paşa’nın keyfi uygulamalarının kontrol edilmesini sağlayacak bir görevlinin denetçi görevini üstlenmesine karar vererek kurumu tekrar işler bir hale sokmuştur. ${ }^{111}$

\section{Sonuç}

$\mathrm{Bu}$ çalışmada, incelenen arşiv belgeleri üzerinden, erken Tanzimat döneminde gerçekleşen yenileşme girişimlerinde Britanya ve ABD’nin; Fransa'dan çok daha büyük ölçüde örnek alındığı ortaya konulmuştur. Oysaki Osmanlı modernleşmesi üzerine olan literatüre hâkim yaklaşım bir bütün olarak Osmanlı modernleşmesini Fransız etkisi çerçevesinde değerlendirmek yönündedir. Bu eğilim, Osmanlı modernleşmesine dair temel başvuru kaynağı niteliği taşıyan eserlerde sıkça karşımıza

107 İlber Ortaylı, “Osmanlı İmparatorluğu’nda Amerikan Okulları Üzerine Bazı Gözlemler”, Amme İdaresi Dergisi, Cilt 14, No 3, s. 87.

108 Ortaylı, Osmanl İmparatorluğu'nda, ss. 89-90.

109 Rodkey, Lord Palmerston, Part II, ss. 196-197.

110 TNA, FO 78/561, No.200, Canning'den Aberdeen'e, 17 Eylül 1844.

111 TNA, FO 78/562, No.220, Canning'den Aberdeen'e, 8 Kasım 1844. 
çlkmaktadır. ${ }^{12}$ Söz konusu eserlerde Osmanlı modernleşmesi sorunsalı, Lale Devri ve III. Selim dönemi modernleşme hareketinin itici gücünün askeri modernleşme oluşu ve Fransa'nın düzenli ordusundan ilham alınarak Osmanlı askeri reformlarının Fransız modelinden etkilenmesi üzerine kurgulanmaktadır. ${ }^{13} \mathrm{Bu}$ dönemde Fransa'nın hususi bir yerinin olduğ $\mathrm{u}^{114}$ doğru olmakla beraber izleyen dönemlerdeki değişimlerin yeterince altının çizilmemesi Osmanlı modernleşme sürecinin Fransız Devleti modeline doğru evirilen düz bir çizgisel gelişim perspektifinden okunması sonucunu doğurmaktadır. Diğer taraftan, kanunlaşma hareketleri, ${ }^{115}$ bürokratik/idari değişim ile ona eşlik eden merkezileşme çabaları ${ }^{116}$ ve modernleşmeye önderlik eden yeni aydın tipi ${ }^{117}$ hususlarında -ve belirli dönemlerde- Fransa etkisinin öne çıktığı da bir gerçektir. Fransız merkeziyetçiliğinin Osmanlı reformlarına, özellikle de bürokratik yenileşmeye uygun gelmesi bu husustaki tarih yazımına egemen olmuştur, denilebilir. ${ }^{18}$ Fakat bu etkinin bir bütün olarak tüm Osmanlı yenileşme tarihine yayılması doğru ve yerinde bir değerlendirme olmamaktadır. Her şeyden önce, Osmanlı modernleşmesi mevzusu kanunlaşma hareketi, bürokratik yapıdaki değişim ve yeni aydın tipinin oluşumunun ötesinde veçheleri de içerisinde barındıran çok boyutlu bir sorunsalı işaret etmektedir. Devlet aygıtından devlet-birey ilişkisine, ekonomik dönüşüm ve teknolojik altyapıdan sosyo-kültürel üstyapıya topyekûn bir dönüşüm söz konudur. Çalışma içerisinde, teknoloji transferi, devlet-birey ilişkisi ve ekonomik dönüşüm gibi alanlardaki Anglosakson etkisi açığa çıkarılmış ve böylelikle literatürde ön plana çıkarılan Fransız etkisinin yanı sıra Anglosakson etkisinin altı çizilerek konuya dair daha geniş perspektifli bir analizin oluşumuna katkı sağlamaya çalışılmıştır.

Osmanlı modernleşmesi sürecini, dış politika merkezli yönelimlerden ziyade, tematik başlıklar üzerinden inceleyip Fransız -Alman veya Anglosakson- ekolünün etkisinin ortaya konulması mevcut literatürümüzün temel yaklaşım tarzını oluşturmaktadır. Çalışma içerisinde incelenen belgeler ve yapılan kıyaslamalar, konuya İmparatorluğun dönemsel dış politikaları ekseninde belirlenip mevcut koşullara göre değişebilen stratejik ortakları bağlamında yaklaşılmasının daha bütünlükçü bir perspektif sunabileceğini göstermiştir. Osmanlı modernleşmesine yabancı etkisi bağlamında bakılacağı zaman dış politikada uyum prensibinin, dış politika merkezli yönelimlerin temel kıstas olarak alınması gerektiği çalışmada varılan önemli sonuçlardan biridir. Tarihsel sürece bakıldığında da görülmektedir

112 Bu konuda ilk akla gelen örnekler şöyledir: Hıfzı Veldet, "Kanunlaştırma Hareketleri ve Tanzimat”, Tanzimat I, İstanbul, MEB, 1999, ss. 139-209; Hilmi Ziya Ülgen, “Tanzimat’tan Sonra Fikir Hareketleri”, Tanzimat I, İstanbul, MEB, 1999, ss. 756-775; Ercüment Kuran, “Osmanlı İmparatorluğu'nda Yenileşme Hareketleri”, Türk Dünyası El Kitabı, Ankara, Türk Kültürünü Araştırma Enstitüsü Yayınları, 1992, ss. 491-507; Niyazi Berkes, Türk Çağdaşlaşması, İstanbul, YKY, 2006; Bernard Lewis, Modern Türkiyénin Doğuşu, çev. Metin Kıratl, Ankara, TTK, 2007; Eric Jan Zürcher, Modernleşen Türkiyénin Tarihi, çev. Yasemin Saner, İstanbul, İletişim, 2009; Kemal Karpat, Osmanlı Modernleşmesi, çev. Akile Zorlu Durukan ve Kaan Durukan, Ankara, İmge, 2008; Stanford J. Shaw ve Ezel Kural Shaw, Osmanl İmparatorluğu ve Modern Türkiye, Cilt. I-II, çev. Mehmet Harmancı, İstanbul, E Yayınları, 2008; Musa Çadırcı, Ülke Yönetimi: Tanzimat Sürecinde Türkiye, Ankara, İmge, 2011.

113 Shaw, Osmanl İmparatorluğu, ss. 316-322, Berkes, Türkiye'de Çağdaşlaşma, ss. 96-97; Lewis, Modern Türkiye'nin, ss. 5960; Karpat, Osmanlı Modernleşmesi, ss. 83-84; Zürcher, Modernleşen Türkiye, ss. 44-45, 47-51.

114 Shaw, Osmanlı İmparatorluğu, s. 323.

115 Kuran, Osmanlı İmparatorluğu'nda, s. 497; Veldet, Kanunlaşma Hareketleri, s. 139-209; Zürcher, Modernleşen Türkiye, s. 99-101; Shaw ve K. Shaw, Osmanlı İmparatorluğu, c. II, s. 98; Ali Akyıldız, Tanzimat Dönemi Osmanlı Merkez Teşkilâtında Reform (1836-1856), İstanbul, Eren, ss. 255, 280.

116 Kuran, İmparatorluğu’nda, s.494, 498; Zürcher, Modernleşen Türkiye, ss. 95-96, 98; Çadırcı, Ülke Yönetimi, s. 293; Karpat, Osmanl Modernleşmesi, ss. 83-84; Ortayl, İmparatorluğun En Uzun, s. 144, 160.

117 Zürcher, Modernleşen Türkiye, s. 74-75; Lewis, Modern Türkiyénin, s. 61-63; Şerif Mardin, Yeni Osmanlı Düşüncesinin Doğuşu, İstanbul, İletişim, 2009, s. 250.

118 Ortaylı, İmparatorluğun En Uzun, ss.160-161. 
ki Osmanlı İmparatorluğu’nda modernleşme hususunda işbirliği yapılan ülke dönemsel dış politika stratejilerine bağlı olarak değişmektedir. Aslında tam da bu yüzden Osmanlı modernleşmesinin başlangıcı olarak kabul edilen Lale Devri ve III. Selim döneminde Fransa model olarak alınmıştır. Zira söz konusu dönemlerde Fransa Osmanlı İmparatorluğu’nun sadece modernleşme konusundaki ortağı değildi, aynı zamanda Rusya'ya karşı da Fransa ile stratejik bir ortaklık kurulmuştu. 18. yüzyılda ve hatta 19. yüzyılın başında Fransa "geleneksel dost” olarak tanımlanmaktaydı. Napoléon'un Mısır’ı işgaline kadar aslında durum böyleydi ve tam da bu sebeple 1798-1802 yılları arasında Fransa ile modernleşme hususunda kurulan işbirliği kesintiye uğramıştı. ${ }^{119}$ Hünkâr İskelesi’nden Kırım Savaşı́na uzanan dönemde ise hem İmparatorluğun dış politikadaki ortağı hem de - modernleşme hamlelerindeki desteği Fransa'dan ziyade Britanya'dır. ${ }^{120}$ Aynı şekilde ABD’nin de bu süreçte Britanya'yla paralel giden bir siyaset güttüğü görülmektedir. 19. yüzyıl boyunca dış politikalarında ortaklığın izlerine rastlanan $A B D$ ve Britanya, Osmanlı ve Doğu siyasetinde de ortak bir çizgi belirlemişlerdir. Bu dönem içerisinde, 1830 'da Osmanlı İmparatorluğu ile ilk anlaşmasını imzalayarak diplomatik ilişki kuran ABD, Britanya'yla işbirliği halinde birçok konuda Osmanlı İmparatorluğu’nu yönlendirmeye çalışmıştır.

Bu açıdan, dönemin başat gücü olarak değerlendirebileceğimiz Britanya ve onun halefi olduğu kadar pek çok konuda da ortağı olan ABD; bu dönemde Osmanlı modernleşmesi üzerinde hukukiidari, ticari-ekonomik yapılanmadan, askerlik ve vergi yapılandırmasına kadar birçok farklı konuda belirleyici rol üstlenmiştir. Örneğin, çalışma içerisinde mercek altına alınan Tanzimat yıllarında ekonomik, hukuki ve askeri modernleşmede Britanya etkisi baskın bir biçimde kendini gösterirken; teknoloji transferi gibi oldukça mühim bir alanda Britanya’nın söz konusu önceliğini ABD’yle paylaşmakta olduğuna, eğitim ve sağlık alanında ise, misyoner faaliyetleri aracılığıyla, ABD etkisinin öne geçtiğine şahit olmaktayız.

119 Lewis, Modern Türkiye'nin, s. 60.

120 Benzer bir biçimde Kırım Savaşı ve hemen akabinde, uluslararası politikada değişen dengelerin etkisiyle, Osmanlı modernleşmesindeki Fransız etkisinin arttığına şahit olmaktayız. Bu konuda ayrıntılı bilgi için bkz. Kuntay Gücüm, İmparatorluğun "Liberal" Yılları (1856-1870), İstanbul, Tarih Vakfi Yurt Yayınları, 2015. 